原著

\title{
非出血性前頭蓋窩硬膜動静脈奇形の検討
}

\author{
川口務, 河野 輝昭, 本間 輝章, 金子 好郎 \\ 堤 正則, 堂坂 朗弘, 大井川秀聡, 風川 清*
}

\section{Non-hemorrhagic Dural Arteriovenous Malformations of the Anterior Cranial Fossa}

Tsutomu Kawaguchi, M.D., Teruaki Kawano, M.D., Teruaki Honnma, M.D., Yoshirou Kaneko, M.D., Masanori Tsutsumi, M.D., Akihiro Dousaka, M.D., Hidesato Ooigawa, M.D., and Kiyoshi Kazekawa, M.D.*

Department of Neurosurgery, Fukuoka Tokushukai Hospital, and *Department of Neurosurgery, Fukuoka University School of Medicine, Fukuoka, Japan

\begin{abstract}
Summary: In the dural arteriovenous malformations of the anterior fossa, the incidence of intracranial hemorrhage is high. We studied 4 patients with nonhemorrhagic dural arteriovenous malformations of the anterior cranial fossa.

There were 3 males and 1 female. Two patients presented with frontal headaches and 2 patients were diagnosed incidentally.

Angiograms revealed the dural arteriovenous malformations fed by the anterior ethmoidal, middle meningeal, superficial temporal and anterior cerebral arteries. The draining veins were pial veins of the frontal lobe into the superior sagittal sinus and cavernous sinus. In all patients, angiograms demonstrated neither venous aneurysm nor varix. Operations were performed successfully on 2 patients. We analyzed the clinical features and radiological findings in 17 repored cases and our 4 cases of the nonhemorrhagic dural arteriovenous malformations.

There were 17 males and 4 females ranging in age from 38 to 69 (mean age of 58.5).

Headache was the reason for presentation in 5 cases, ocular symptoms in 6 , seizure in 1 , and tinnitus in 1 . Eight cases were diagnosed incidentally. Angiographically, 6 cases had venous aneurysms or varix. This frequency was extremly low compared with hemorrhagic dural arteriovenous malformations of the anterior fossa. These findings indicated that a patient with dural arteriovenous malformations associated with a venous aneurysm has an increased risk of hemorrhage.

Venous aneurysm should be treated aggressively.

With a venous aneurysm, aggressive treatment should be done.
\end{abstract}

\author{
Key words: \\ - dural arteriovenous mal- \\ formation \\ - anterior cranial fossa
}

Surg Cereb Stroke

(Jpn) 27: 24-30, 1999

\section{はじめに}

前頭蓋窩硬膜動静脈奇形は，1963年 Lepoire らにより報
告され ${ }^{8)}$, 硬膜動静脈奇形の約 $6 \%$ を占める ${ }^{7)}$. 中年男性 に多く, 80\% 以上が頭蓋内出血で発症するなどの特徵を 有す.今回われわれは, 非出血性の前頭蓋窩硬膜動静脈奇 福岡徳洲会病院 脳神経外科(受稿日 1998.7.6)〔連絡先： $7816-0861$ 福岡県春日市須玖北 4-5 福岡徳洲会病院 脳神経外科 川口 務〕〔Mailing address: Tsutomu KawAGuchI, M.D., Department of Neurosurgery, Fukuoka Tokushukai Hospital, 4-5, Sukukita, Kasuga, Fukuoka 816-0861, Japan] 
Table 1 Clinical summary of 4 cases with anterior cranial fossa non-hemorrhagic DAVMs

\begin{tabular}{|c|c|c|c|c|c|c|c|c|}
\hline Case & Age/Sex & Clinical presentation & Side & Feeding vessels & Draining veins & VA & Surgery & Outcome \\
\hline 1 & $55 / M$ & Frontal headache & Rt & BAEA & CS, SSS & no & yes & $G R$ \\
\hline 2 & $67 / M$ & Incidental (B|) & Lt & BAEA & CS, SSS & no & yes & GR \\
\hline 3 & $60 / M$ & Frontal headache & Lt & $\begin{array}{l}\text { Rt AEA, ACA, } \\
\text { L } S T A, M M A\end{array}$ & CS, SSS & no & no & \\
\hline 4 & $58 / F$ & Incidental (ICH) & Rt & Rt AEA & SSS & no & no & \\
\hline
\end{tabular}

BI: Brain Infarction, $\mathrm{ICH}$ : Intracerebral Hemorrhage, BAEA: Bilateral Anterior Ethmoidal Artery, AEA: Anterior Ethmoidal Artery, ACA: Anterior Cerebral Artery, STA: Superficial Temporal Artery, MMA: Middle Meningeal Artery, CS: Cavernous Sinus, SSS: Superior Sagittal Sinus, VA: Venous Aneurysm, DAVMs: Dural Arteriovenous Malformations, GR: Good Recovery
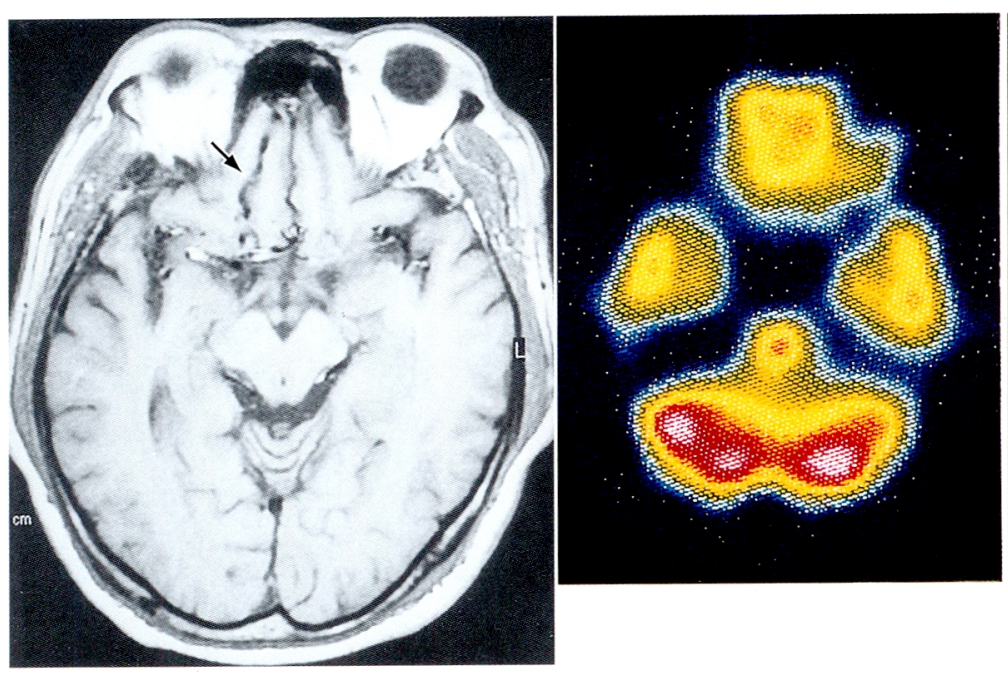

Fig. $1 \mathrm{~A}$

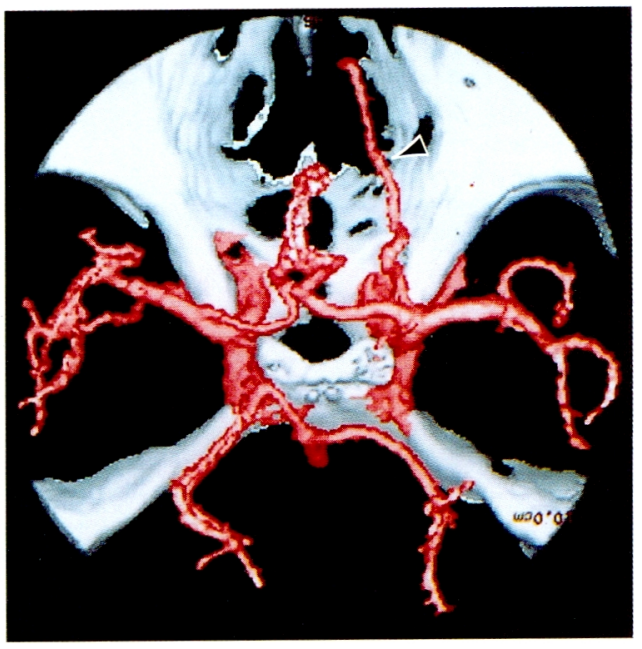

A $\mid$ B $\mid$ C
形 4 症例を経験したので報告し，涉猟しえた非出血性の前 頭蓋窩硬膜動静脈奇形 17 症例を加え検討する.

\section{対象}

4 症例を Table 1 に呈示する。年齢は 55，67，60，58歳 と中高年で, 男性 3 例女性 1 例で, 非出血性前頭蓋窩硬膜 動静脈奇形である。発見の契機は, 頭痛の精査にて施行し たMRI，3D-CTA で発見されたもの 2 例, 脳梗塞, 脳出血 に施行した脳血管撮影で発見されたもの 2 例である。 4 症 例中 2 例で手術を施行した。脳出血で発症した 1 例は肝硬 変を伴っており保存的に加療し, 他の1例は手術の同意が 得られず経過観察とした。

\section{代表症例}

手術を施行した2症例を呈示する.

〈症例 1〉55 歳男性.

平成 8 年 9 月約 1 力月持続する前頭部を中心とした頭痛
を訴え, 当科を受診した。家族歴として, 兄が脳動脈瘤破 裂によるくも膜下出血をきたしており，脳血管の精査を希 望していた。

神経学的所見：意識は清明で神経脱落症状はなかった. 前額部で雑音は聴取されなかった。

神経放射線学的検査：3D-CTA では右前頭蓋底に1本の 拡張した異常血管を認め, MRIで右嗅溝に拡張蛇行した 無信号領域が存在した(Fig. 1). 脳血管撮影では両側前篩 骨動脈を流入動脈とする右側の前頭蓋窝硬膜動静脈奇形を 認めた。静脈瘤は存在せず, 右前頭葉底部の拡張蛇行した 皮質静脈老経て, 海綿静脈洞に流出し, 一部は上矢状洞に 流出していた(Fig. 2)。しかし, その周囲に静脈うっ滞な どは認められなかった。 ${ }^{123}$ I-IMP-SPECTでは前頭葉の血 流低下もなく，その他の脳血流量の異常もなかった(Fig. 1).

手 術：岀側前頭開頭術を行い, 硬膜を切開翻転し, 彩 冠に到達した。右側篩板には前篩骨動脈からの異常血管を 


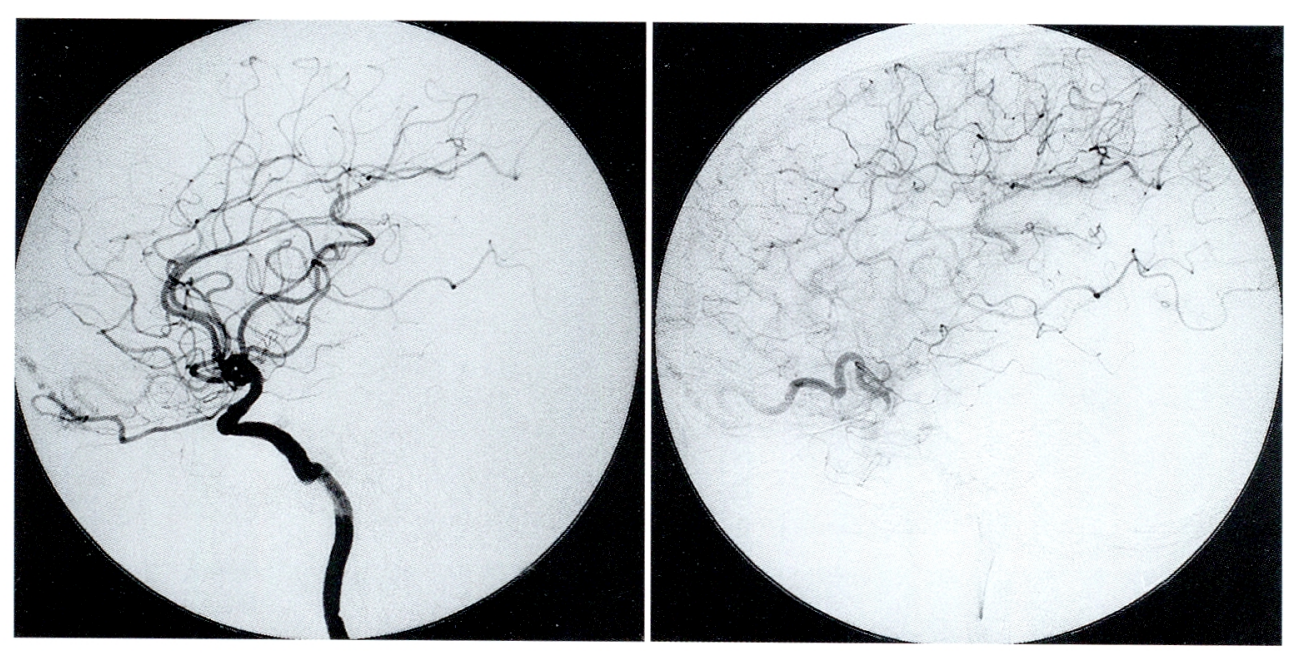

Fig. 2 Right internal carotid angiograms demonstrating dural arteriovenous fistula at the anterior cra- $\quad$ A $\mid$ B

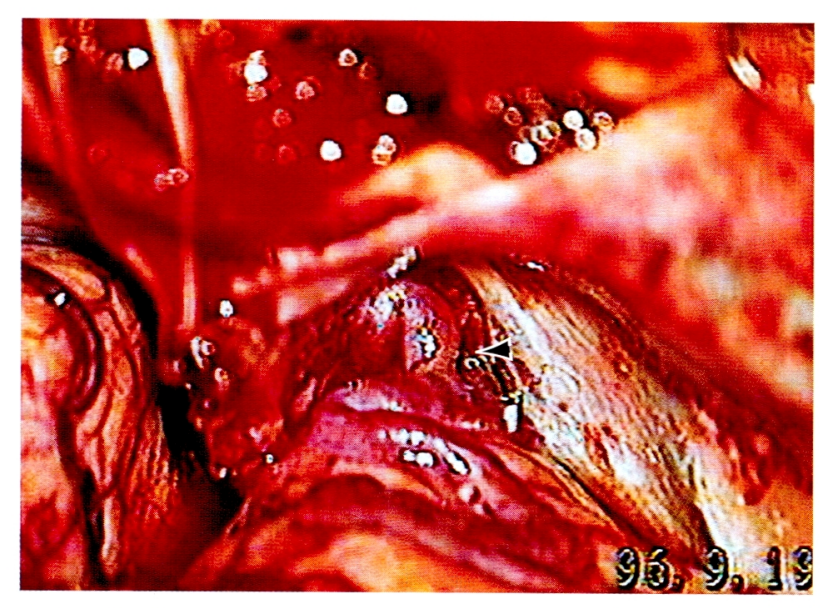

Fig. 3 Operative photograph demonstrating dural arteriovenous fistula at the right cribriform plate and an enlarged red vein (arrowhead).
認め，これは右側の赤色静脈に連なっていた (Fig. 3)。 部分は前頭盍底の拡張した皮質静脈を経て海綿静脈洞方向 へ，一部は右前頭葉脳表静脈を経て上矢状洞へ流出してい た。篩板で異常血管を bipolarで凝固し切断した。篩板付 近の硬膜にドップラーをあて, 動静脈瘻の離断が十分であ ることを確認した。 なお，右嗅神経の温存はできなかった． 右側の無嗅症は残存したが，患者の自覚はなく，術後経 過は良好で他の神経脱落症状はなく独歩退院した。また術 後脳血管撮影では前頭蓋窩硬膜動静脈奇形は消失した

(Fig. 4).

〈症例 2〉67 歳男性.

平成 9 年 4 月 18 日軽度の右上下肢の脱力を訴元, 翌日

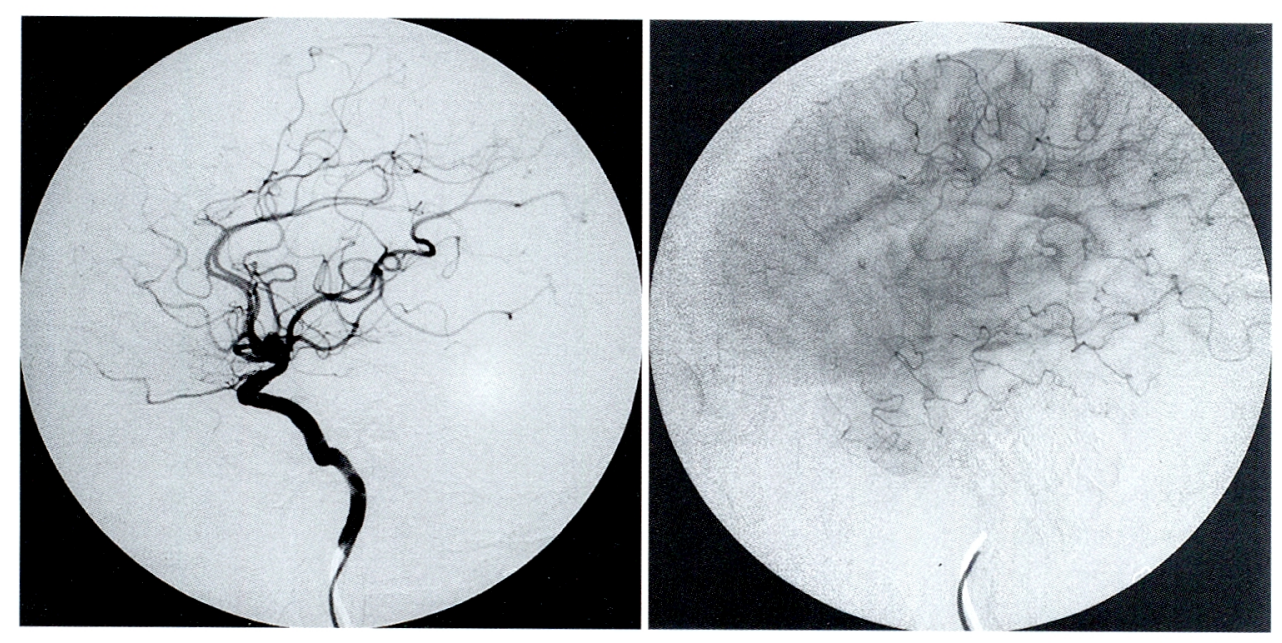

Fig. 4 Right internal carotid angiograms revealing the disapperance of the dural arteriovenous fis- $\quad$ A $\mid$ B 

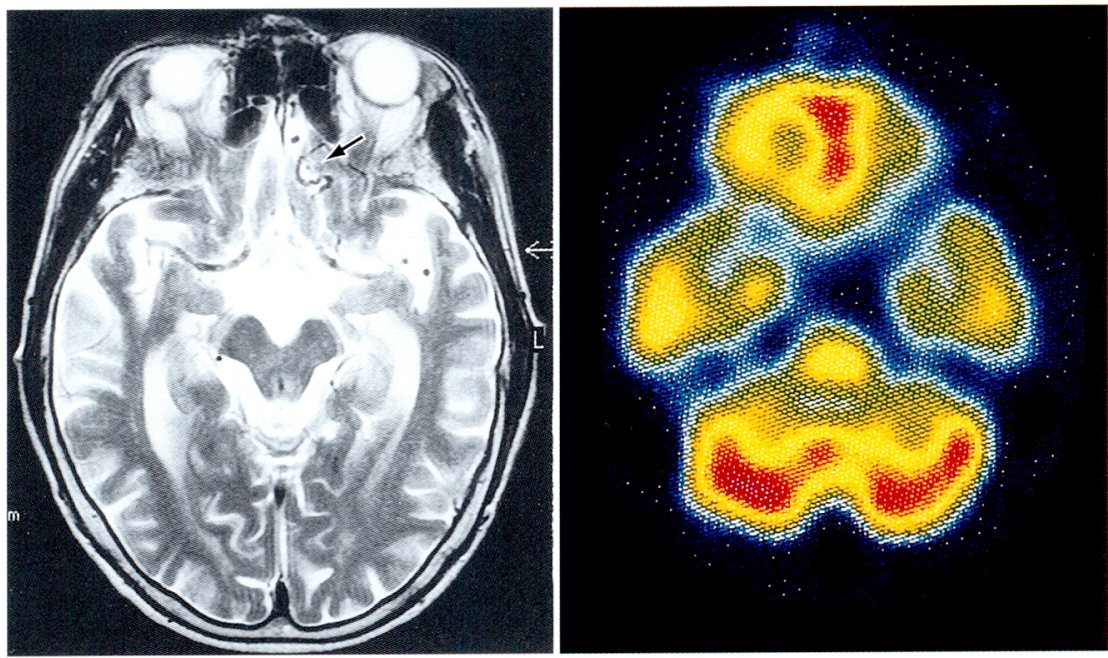

Fig. 5 A: T2-weighted imaging showing flow void (arrow) at the left frontal region. B. ${ }^{123}$ HMP SPECT revealing no low perfusion area in the left frontal region.

当科を受診した。

神経学的所見：意識は清明で軽度の右不全片麻痺を認め た。前額部で雑音は，聴取されなかった。

神経放射線学的所見：MRIT2 強調画像では, 左:基底核 に小さな高信号域を認め脳梗塞と診断した。この病変とは 別に左前頭蓋底に屈曲蛇行する無信号域を認めた(Fig. 5). 脳血管撮影では，左内頸動脈分岐部に70\%の狭窄を認め た.さらに左側優位で両側前篩骨動脈を流入血管とする前 頭蓋窩硬膜動静脈奇形を認めた。流出血管は, 左前頭葉底 部の拡張蛇行した皮質静脈で，これは左海綿静脈洞へ，一 部は上矢状洞に流出していた Fig. 6). 静脈瘤は存在せず, また静脈うっ血も存在しなかった。左頸動脈狭乍症に対し ては, 5 月 8 日内膜剝離術を行った。 その後, リハビリを 行い右不全片麻痺は完全に改善した. 6 月 6 日の ${ }^{123}$ I-IMPSPECTでは, 前頭部の血流低下もなく，他の部位におい ても脳血流量の低下は認められなかった(Fig. 5).

手 術：6月12日前頭蓋窩硬膜動静脈奇形に対し手術 を施行した。両側前頭開頭を行い左側の嗅神経の外側に異 常血管を認め, これは赤色静脈に連なっていた(Fig. 7). この異常血管を凝固し切断した。結局, 左嗅神経は離断さ れた。篩板付近の硬膜にドップラーをあてると, わずかに 動静脈瘦の残存があり,さらに凝固を行った。

術後の血管撮影では前頭蓋窩硬膜動静脈奇形は完全に消 失しており，またMRIで無信号領域は消失し, 3D-CTA でも異常血管は消失した (Fig. 8). 左の無嗅症のみ残存し 他の神経脱落症状なく独歩退院した.

\section{考案}

硬膜動静脈奇形は存在部位により，異なった臨床上の特

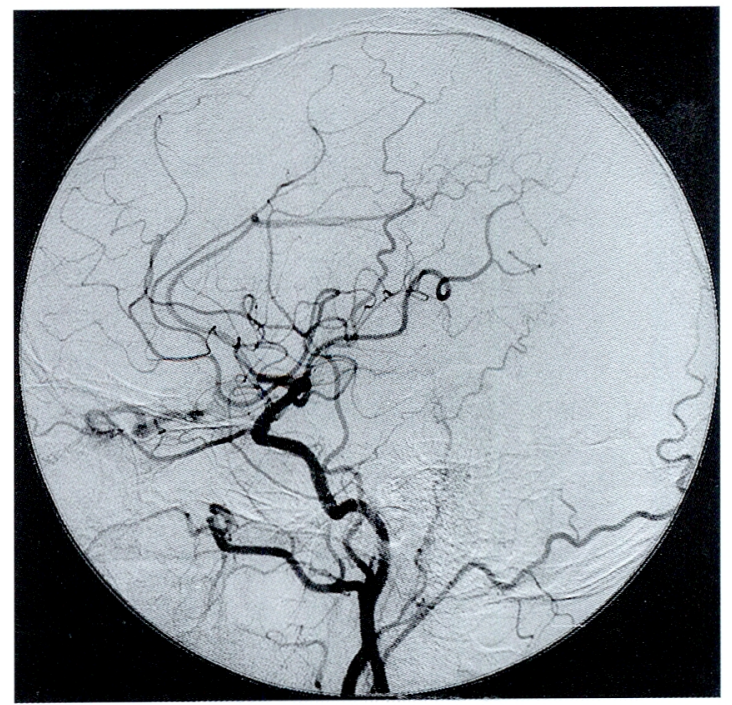

Fig. 6 Left common carotid angiograms showing dural arteriovenous fistula of the anterior cranial fossa by the anterior ethmoidal artery. The venous aneurysm was not demonstrated

徵を有している. King, Martinらは, 前頭蓋窩硬膜動静 脈奇形について自験 9 例を含め 26 例を分析し報告してい る7)。それによると男性 $77 \%$ ，女性 $23 \%$ と圧倒的に男性に 多く，40 代 19\%，50 代 46\%，60 代 35\% で平均年齢 55 歳 で中高年で発症している。出血発症は 21 例 $81 \%$ にのぼり, 非出血症例は眼球突出 2 例, 頭痛 1 例, 耳鳴り 1 例, 後頭 葉の脳内出血に合併した偶発 1 例である.

硬膜動静脈奇形の自然歴は,いまだ解明されていないが, Awadらは, 危険な硬膜動静脈奇形として, 皮質静脈への 


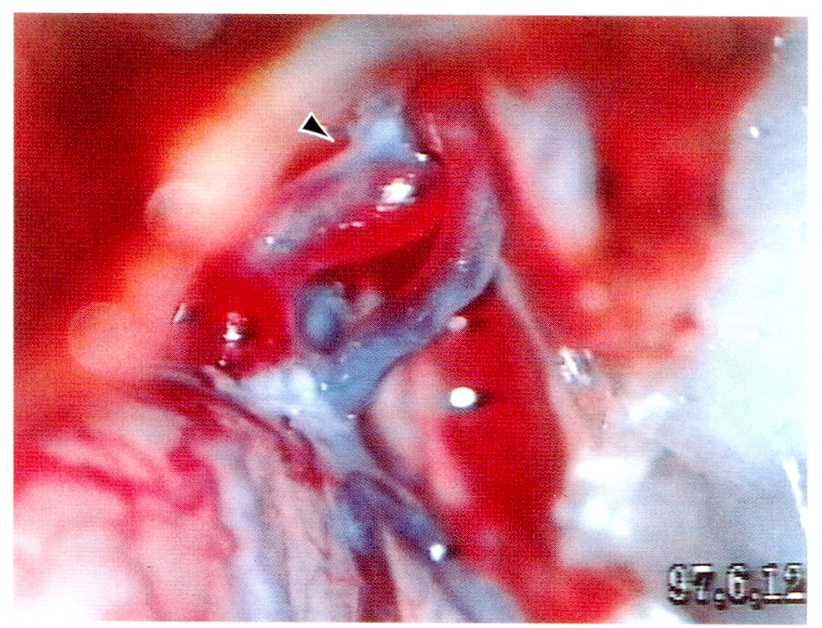

Fig. 7 Operative photograph showing dural arteriovenous fistula at the left cribriform plate and enlarged red veins (arrowhead)

流出, 静脈溜の存在, ガレン静脈への流出をあげている22. 前頭蓋窝硬膜動静脈奇形は, 横静脈洞-S 状静脈洞や海綿 静脈洞などの硬膜動静脈奇形と比較し, 出血をきたしやす いとされている。その原因は前頭蓋窩硬膜動静脈奇形は, 他の部位の硬膜動静脈夺形と異なり, 静脈洞の近傍に存在 するのではなく，常に流出血管として皮質静脈への流出が 存在しており, 脳動静脈奇形の出血率に類似するのではな いかと考えられている7)。さらに重要な要因としてあげら れるのが静脈瘤の存在で, 静脈溜から出血したとする報告 が多数みられる

Table 2 に渉猟しえた血管撮影所見が詳述された非出血.
Table 2 Clinical summary and radiographic features of patients with non-hemorrhagic DAVMs of anterior cranial fossa

\begin{tabular}{|c|c|c|}
\hline Sex & $\begin{array}{l}\text { Male } \\
\text { Female }\end{array}$ & $\begin{array}{l}17(81 \%) \\
4(19 \%)\end{array}$ \\
\hline Age & $\begin{array}{l}30-39 \\
40-49 \\
50-59 \\
60-69\end{array}$ & $\begin{array}{l}1(5 \%) \\
0 \\
9(43 \%) \\
11(52 \%)\end{array}$ \\
\hline Clinic & $\begin{array}{l}\text { Presentation } \\
\text { Headache } \\
\text { Visual loss, Amaurosis Fuga } \\
\text { Exophthalmos } \\
\text { Seizure } \\
\text { Tinnitis } \\
\text { Trochlear nerve palsy } \\
\text { Incidental } \\
\text { ISAH: 1, ICH: 3, BI: 2, CC }\end{array}$ & $\begin{array}{l}x \\
F: 11\end{array}$ \\
\hline Feedi & $\begin{array}{l}\text { Artery } \\
\text { Anterior ethmoidal artery } \\
\text { Internal maxillary artery } \\
\text { Superior temporal artery } \\
\text { Middle meningeal artery } \\
\text { Anterior cerebral artery }\end{array}$ & $\begin{array}{r}21 \\
5 \\
4 \\
3 \\
2\end{array}$ \\
\hline Veno & $\begin{array}{l}\text { Drainage } \\
\text { Superior sagittal sinus } \\
\text { Cavernous sinus } \\
\text { Basal vein }\end{array}$ & $\begin{array}{r}18 \\
6 \\
4\end{array}$ \\
\hline Veno & aneurysm & $6(28.6 \%)$ \\
\hline
\end{tabular}
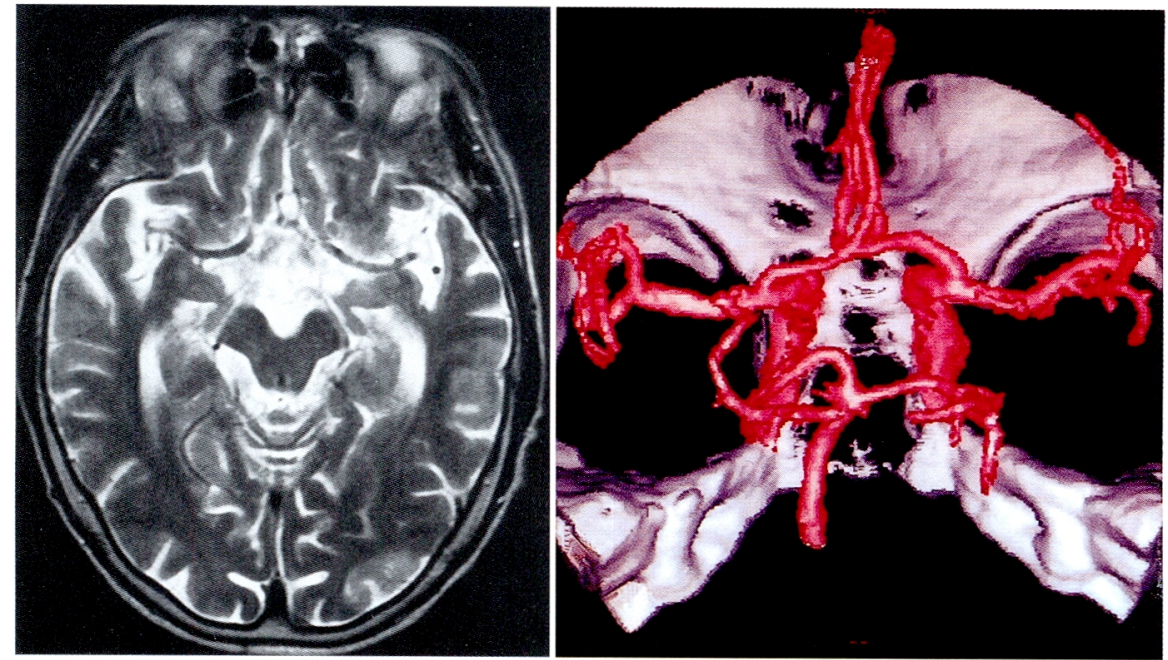

Fig. 8 A: T2-weighted imaging demonstrating the disappearance of the flow void at the left frontal region.

B 3D-CT angiography showing no abnormal vessel.

A $\mid$ B 
性の前頭蓋窩硬膜動静脈奇形 17 症例に自験 4 例を加えた 21 症例の非出血性前頭蓋窩硬膜動静脈奇形の要約を示

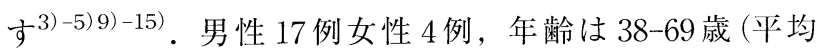
58.5 歳)であった。発見された理由および症状として, 脳 内出血, 〈も膜下出血, 脳梗塞, 頸動脈海綿静脈洞瘻に施 行された血管撮影で発見された偶発例 8 例, 頭痛 5 例, け いれん 1 例, 耳鳴り 1 例, 眼症状 6 例である. 流入血管は, 前篩骨動脈は 21 例全例, 上顎動脈 5 例, 浅側頭動脈 4 例, 中硬膜動脈 3 例, 前大脳動脈 2 例である. 流出血管は上矢 状洞 18 例, 海綿静脈洞 6 例, 脳底静脈 4 例であった。ま た本報告を含めた 21 症例の非出血性前頭蓋窩硬膜動静脈 奇形においては，静脈瘤は，6例 $28.6 \%$ に認められた。こ れは，前述の King, Martin らの報告 ${ }^{7)}$ と比較するときわ めて低率である.この結果からも, 出血の原因として静脈 瘤の存在が重要な要因の一つと考えられる，本疾患におい て, 流出血管の皮質静脈が動脈圧により拡張蛇行し, さら に屈曲部などに hemodyanmic stressが加わり, 静脈瘤が 生じ, これが出血するのではないかと推定される.よって, 皮質静脈を常に流出血管として有す前頭蓋窩硬膜動静脈奇 形は，危険なもので治療すべきであり，静脈瘤を伴ったも のは, さらに出血しやすい状態と考えられ, より積極的な 治療が必要と考えられる。したがって, 本報告の 4 例でも 静脈瘤は存在しなかったが, 流出静脈の拡張蛇行が認めら れたため, 全例手術適応があると考えられた。 また本報告 を含めた文献例 21 症例の非出血性前頭蓋窩硬膜動静脈奇 形においては，本報告例 2 例を含め 13 例が開頭術による 治療が施行され，その中で 4 例が静脈瘤を伴っていた。

硬膜動静脈奇形には, 静脈洞閉塞あるいは静脈性高血圧 のため頭蓋内に静脈うっ滞を生じ出血をきたしたり, 痴呆 や神経脱落症状をきたすことがしばしば報告されてい $る^{2)}$ 。本疾患では，流出血管が上矢状洞や海綿静脈洞であ ることが多く，これらの静脈洞の圧が上昇し，頭蓋内に静 脈のうっ滞をきたす病態も予想されうるが，このような報 告は渉猟しえた範囲では皆無である。本報告では，2例で ${ }^{123}$ I-IMP-SPECTを施行したが，前頭蓋窩硬膜動静脈奇形 の存在部位近傍や他の部位の脳血流量低下は認められなか った。この理由として, 本疾患では横静脈洞 S 状静脈洞の 硬膜動静脈奇形などとは異なり，静脈洞の閉塞や狭窄が関 与せず，またこの 2 症例では，シャント量が少なく，動脈 血が流出血管である皮質静脈, 静脈洞に流入しても静脈う っ滞を生じるまでの静脈性高血圧をきたさなかったのでは ないかと考えられる。

非出血性前頭蓋窩硬膜動静脈奇形 21 症例中 6 例に眼症 状がみられている。 3 例は視力低下 ${ }^{5)} \cdot$ 黑内障 $^{14)}, 2$ 例は

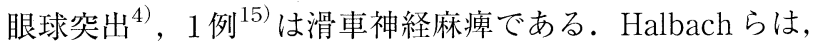
視力低下にて発症した前頭蓋窩硬膜動静脈奇形に対して手
術を施行し，その改善を認めた 2 症例を報告している. 彼 らは視力低下の機序として, 眼動脈から前頭蓋窩硬膜動静 脈奇形への盗血による症状，あるいは，海綿静脈洞に流出 していたことから上眼静脈の圧が上昇し，この部位で静脈 うっ滞をきたし視力障害を生じたのではないかと考察して いる5).

MRI P 3D-CTA で本疾患を診断することは比較的容易 であり，脳ドックなどで非出血性の前頭蓋窩硬膜動静脈奇 形の診断も可能である. 今後, 非出血性前頭蓋窩硬膜動静 脈奇形の症例が蓄積され，どのようなものが出血しやすい のか，また頭蓋内に静脈うっ血，静脈性脳虚血をきたすよ うな病態は存在しないのかなど, さらなる解明が期待され る.

治療には，開頭術，血管内外科による治療，放射線療法 などがある，開頭術では，前頭蓋窩硬膜動静脈奇形を含む 硬膜と流出静脈の離断により治療される。静脈瘤は, この 手技により血检化縮小し, 摘出の必要はないと報告されて おり ${ }^{7)}$, 本報告でも同様であった。われわれの症例では, 離断後, ドップラーを篩板付近の硬膜にあてると, わずか に動静脈瘻の残存が認められ，本手術に有効であった。開 頭術による治療にも，咱神経の温存が困難な点や術後の髄 液漏などの問題もあるが，現時点では，手術が治療の第一 選択と考えられる。

本疾患に対する血管内外科による塞栓術は，これまで数 例報告されているが(1)6)15), 眼動脈閉塞など危険性もあり, 現時点では治療の第一選択とすべきではないとされている 5) 9）。今後，技術の進歩，塞栓物質などの改良により治療 方法の一つとなることが期待される。また放射線治療に関 しては, 硬膜動静脈奇形の血栓化が得られるまで $1-2$ 年を 必要とし, 出血例では推奨されない ${ }^{7)}$. 開頭術による治療 が安全で有効な方法ではあるが, 本報告のごとく, 非出血 例で，静脈瘤を伴っていない症例や眼症状を伴っていない 症例では, 放射線治療も治療方法の一つと考えられる.

\section{文献}

1）鐙谷武雄，上山博康，阿部弘，ほか：特異な draining vein を有した前頭蓋底部硬膜動静脈奇形の一例．Neurol Med Chir (Tokyo) 27: 1195-1200, 1987

2) Awad IA, Little JR, Akrawi WP, et al: Intracranial dural arteriovenous malformations: factors predisposing to an aggressive neurological course. J Neurosurg 72: 839-850, 1990

3) Bitoh S, Nakagawa H, Arita N, et al: Dural arteriovenous malformation in the anterior fossa. case report. Neurol Med Chir (Tokyo) 21: 131-134, 1981

4) Driesen W, Elies W: Uber drei Falle intrakranieller arteriovenoser Mi bildungen mit arterieller Versorgung aus der Arteria ethmoidea anterior. Neurochirurgia (Stuttg) 15: $178-181,1971$ 
5) Halbach VV, Higashida RT, Hieshima GB, et al: Dural arteiovenous fistulas supplied by ethmoidal arteries. Neurosurgery 26: 816-823, 1990

6）早瀬一幸，鈴木知穀，下道正幸，ほか：前頭蓋窩硬膜動静 脈シャントに対するコイル塞栓術. 第 10 回日本脳神経血管 内手術研究会講演集, 新潟, 1994

7) King WA, Marin NA: Dural arteriovenous malformations. AANS Publications Committee, Park Ridge, 1993, pp 105-116

8) Lepoire J, Montaut J, Bouchot M, et al: Anevrismes arterio-veineux intrafrontaux vascularises par l'artere ethmoidale anterieure. A propos de trois observations. Neurochirurge 9: 159-166, 1963

9) Marin NA, King WA, Spetzler RF, et al: Management of dural arteriovenous malformations of the anterior cranial fossa. J Neurosurg 72: 692-697, 1990
10）松原年生，和賀志郎，小島 精, ほか：前頭蓋窩硬膜動静 脈奇形. 脳卒中の外科 18: 103-108, 1990

11）岡田達也, 松田昌之, 半田譲二：脳動脈瘤と前頭蓋窩硬膜 動静脈奇形の合併. 脳神経外科 16: 903-906, 1988

12) Reul J, Thron A, Laborde G, et al: Dural arteriovenous malformations at the base of the anterior cranial fossa: report of nine cases. Neuroradiology 35: 388-393, 1993

13) Tanaka K, Yonekawa Y, Miyake H: Dural arteriovenous malformation in the anterior cranial fossa: report of a case. Surg Neurol 36: 221-225, 1991

14) Xiong L, Li J, Jinkins JR: Amaurosis fugax caused by a dural arteriovenous fistula from the ophthalmic artery. AJNR 14: 191-192, 1993

15）山本正昭, 福島武雄, 坂元政三郎, ほか：滑車神経単独麻 瘏で発症した前頭蓋底 Mixed Dural-pial Arteriovenous Malformation の 1 例. 脳神経外科 21: 177-181, 1993 